\title{
NOVEL AMERICAN WIFE SITTENFELD KARYA ELIZABETH CURTIS : PENGARUH LAKI-LAKI TERHADAP PEREMPUAN
}

\author{
Supriyono \\ Universitas Gajah Mada \\ Email :supriyono_english@ugm.ac.id
}

\begin{abstract}
Abstrak: Pengaruh laki-laki dalam novel American Wife karya Elizabeth Curtis Sittenfeld menampilkan perempuan dengan dominasi yang mereka miliki. Hal ini menunjukkan adanya sikap ambigu seorang perempuan dalam merespon wacana dominasi laki-laki, ketidakadilan peran perempuan dan penegasan resistensi perempuan terhadap dominasi laki-laki. Dari sini permasalahan utamanya adalah respon subjek dalam menghadapi wacana dominasi laki-laki melalui strategi perlawanan perempuan melalui partisipasi dalam masyarakat. Konsep atau teori dan metode penelitian yang digunakan adalah kualitatif. Hasil yang diperoleh adalah gagasan kesetaraan dalam pendidikan digunakan sebagai strategi perlawanan dalam wacana dominasi laki-laki sekaligus memperkuat resistensi perempuan terhadap dominasi laki-laki. Selain itu, strategi juga mengembangkan gagasan tentang kekuatan perempuan berdasarkan kesetaraan pendidikan, yaitu melalui akses pendidikan tinggi.
\end{abstract}

Kata Kunci: perempuan, dominasi laki-laki, perlawanan, ambiguitas.

\section{NOVEL AMERICAN WIFE SITTENFELD BY ELIZABETH CURTIS: THE INFLUENCE OF MEN ON WOMEN}

\begin{abstract}
The male hegemony in Elizabeth Curtis Sittenfeld's novel American Wife presents women with their dominance. This shows an ambiguous attitude of a woman in responding to the discourse of male domination, the injustice of women's roles and an affirmation of women's resistance to male domination. From here the main problem is the subject's response to the discourse of male domination through women's resistance strategies through participation in society. The concept or theory and the research method used are qualitative. The result obtained is that the idea of equality in education is used as a strategy of resistance in the discourse of male domination as well as strengthening women's resistance to male domination. In addition, the strategy also develops ideas about women's strength based on equality in education, namely through access to higher education.
\end{abstract}

Keywords: women, male domination, resistance, ambiguity.

BASASTRA Jurnal Bahasa, Sastra, dan Pengajarannya

Volume 8 Nomor 2, Oktober 2020, P-ISSN 2302-6405, E-ISSN 2714-9765 


\section{PENDAHULUAN}

Elizabeth Curtis Sittenfeld, seorang penulis perempuan Amerika menghasilkan beberapa karya berupa novel yang membahas tentang dunia perempuan di Amerika abad dua puluh satu. Beberapa karya yang dihasilkan adalahThe Man of My Dream (2006), American Wife (2008), Eligible (2016), Sisterland (2013) . Novel digunakan sebagai bukti mental bagi penelitian ini sebagai produk dari saat berlangsungnya keadaan termasuk orang-orang, dan masyarakat yang tidak dapat dipisahkan dari satu sama lain. Novel merupakan bentuk refleksi atau imitasi dari masyarakat.

Posisi pengarang menunjukkan dalam karya sastra menunjukkan sebuah ambiguitas, keberpihakan pada jalan pikiran seorang perempuan dan sekaligus ketidaksetujuan atas jalan pikiran subyek laki-laki. Fakta ini menjadikan cara pandang bahwa kesastraan merupakan bentuk perjuangan subyek di tengah perjumpaan berbagai tradisi dominasi laki-laki dalam keluarga, jabatan pekerjaan dan juga posisi sosial dalam masyarakat.

Wife (2008), peran seorang istri yang sangat penting dalam menunjang karier seorang suami. Dalam bidang politik yang menunjukkan bagaimana wanita yang sebenarnya memiliki peran yang sangat besar sebagai istri politisi dan dalam sisi yang lain juga memiliki kekuatan yang sama besarnya dengan politisi tersebut harus terpengaruh oleh pandangan laki-laki yang berkuasa. Dalam novel secara garis besar menunjukkan bahwa dominasi laki-laki dalam bidang politik mengpengaruh wanita dalam perannya sebagai warga yang memiliki hak yang sama dalam pemerintahan. Ketika berkaca pada sistem pemerintahan Amerika sejak berdiri hingga saat ini belum pernah ada presiden perempuan. Dalam novel ini diceritakan bagaimana perempuan yang memiliki hak yang sama dalam sistem politik terpengaruh oleh pandangan tentang pemimpin menurut masyarakatnya.

Peneliti menunjukkan novel dengan seorang penulis perempuan Amerika tersebut dengan alasan sebagai berikut: a) Novel itu memiliki karakteristik yang sama yaitu bagaimana laki-laki mendominasi perempuan dalam kehidupan sosial dan masyarakat dan juga sisi ketergantungan perempuan, b)Adanya kesamaan masalah yaitu bagaimana status sosial di masyarakat sangat dipengaruhi oleh dominasi laki-laki. c) Adanya kesamaan tentang masalah perempuan yang selalu tidak percaya diri dengan status sosial yang dimiliki dalam bermasyarakat dan bagaimana mereka mengkompromikan hal tersebut dari sudut pandang penulis perempuan., d) Adanya respon perempuan yang membentuk pola pikir yang berbeda terhadap pengaruh lakilaki dengan mengkounter-pengaruh tersebut. 
Beberapa penelitian awal sebelumnya menegaskan asumsi awal bahwa dalam karya sastra perempuan Amerika yang oleh Curtis Sittenfeld tersebut menunjukkan resistensi terhadap pengaruh laki-laki dan juga menganggap lumrah dominasi laki-laki terhadap perempuan, sikap ambivalen ini merupakan dampak yang ditimbulkan dari dominasi laki-laki terhadap perempuan dalam beberapa bidang baik keluarga, profesi maupun kehidupan sosial kemasyarakatan.

Adapun tujuan dari penelitian ini adalah sebagai berikut, yang bagaimana Curtis Sittenfeld merepresentasikan pengaruh laki-laki terhadap perempuan, dengan menggunakan pandangan sosial untuk menggambarkan pengaruh dalam masyarakat yang terjadi. Yang kedua, mengungkapkan

bagaimana perempuan Amerika menegosiasikan pengaruh laki-laki.

Manfaat utama penelitian ini
adalah sebagai upaya untuk merekonstruksi gagasan tentang perjuangan perempuan, yakni artikulasi perempuan dalam menghadapi dominasi laki-laki sebagai sebuah fakta mentalitas dalam kehidupan perempuan. Manfaat lain yang bisa diperoleh adalah bahwa resistensi perempuan terhadap pengaruh laki-laki adalah bagian yang tidak bisa terpisahkan dalam dinamika masyarakat global yang akan berlangsung terus menerus.

\section{METODE}

Secara metodologis, kajian pascakolonial berupaya untuk mengungkapkan dan menelanjangi kuasa penjajah dibalik sikap, praktik, dan teori masyarakat atau subjek terjajah yang seakan-akan terbebas dari penjajahan itu sendiri. Selain itu, tujuan dari kajian pascakolonial adalah untuk mengungkapkan operasi perlawanan terjajah yang ada di balik teori, sikap, dan praktiknya.

Denzin and Lincoln menguatkan bahwa penelitian kualitatif mencakup pendekatan dengan multimetode untuk memahami pengalaman manusia "Qualitative research use semiotics, narrative, content, discourse, archival, and phonemic analysis, even statistics, tables, graphs, and numbers" (Dezin and Lincoln, 2005: 7). Dalam rancangan penelitian ini, peneliti menggali lebih dalam menurut pendekatan Rekonsiliasi Disiplin, menggunakan pendekatan sejarah, politik, sosial, ekonomi dan budaya dengan mengkaitkan pendekatan pengaruh Gramsci.

Objek kajian material dari penelitian adalah teks American Wife (2008) karya Curtis Sittenfeld. Objek formalnya adalah ambiguitas subjek pengarang perempuan Amerika yang terpengaruh oleh laki-laki dalam menghadapi dominasi laki-laki. Sumber data diperoleh dari teks American Wife (2008) dan semua pustaka yang memiliki relevansi 
dengan topik penelitian. Teknik pengumpulan data dilakukan dengan membaca dan mencatat informasi yang dibutuhkan. Berdasarkan tujuan tersebut, secara umum metode analisis data yang digunakan dalam kajian pengaruh ini menggunakan metode dekonstruksi (Faruk, 2007: 17-18).

Metode ini meliputi beberapa langkah. Pertama, melakukan pembacaan terhadap teks dengan cara pembacaan oposisi biner atas wacana pengaruh yang terdapat dalam novel American Wife (2008) karya Curtis Sittenfeld, guna menemukan gagasan dasar, kesatuan tematik, dan sarana retoris yang memungkinkan menunda dan membuat asumsi tersebut terpecah. Langkah yang kedua adalah melakukan analisis terhadap subjek yang dimaksudkan, sebagai subjek termarjinalkan dan sekaligus mendesentralisasi kesatuan wacana pengaruh laki-laki dengan mendasarkan pada artikulasi yang dikemukan oleh teks yang ditulisnya. Pembacaan ini juga dilakukan dengan cara mengungkapkan relasi subjek yang terpengaruh dengan dominasi laki-laki.

\section{HASIL DAN PEMBAHASAN \\ Pengaruh Laki-laki dalam Kehidupan Sosial}

Pengukuhan Pengaruh Lakilaki: Laki-laki sebagai seorang breadwinner Laki-laki dipandang sebagai yang layak bertanggungjawab dalam mencari nafkah dalam kehidupan keluarga dan dalam kehidupan sosial. Laki-laki berperan cukup besar dalam mencari nafkah. Sejarah mencatat juga bahwa laki-laki menjadi pencari nafkah terlihat dari angkatan kerja Amerika secara umum bahwa angkatan kerja pada awal abad 20 hingga menjelang abad 21 menunjukkan bahwa Amerika sendiri didominasi oleh laki-laki. Bukan hanya angkatan kerja saja tapi dalam kehidupan keseharian bahwa laki-laki diposisikan sebagai yang bertanggungjwab lebih besar dalam menopang ekonomi keluarga. Tanggung jawab yang besar dan juga tuntutan yang diemban juga besar menjadikan laki-laki sebagai pencari nafkah semakin mengukuhkan bahwa laki-laki layak dan juga berhak mendapatkan sesuatu yang lebih dalam penghormatan di dalam masyarakat. supporting character, which is a positive response (Sanditama,2020)

Gramsci menggunakan pengaruh sebagai cara untuk menggambarkan posisi kepemimpinan kelas dalam aliansi kelas-kelas lain. Selanjutnya, kekuasaan didasari, menurut Gramsci, dengan "dual atau diadik oposisi: kekuatan dan persetujuan, kekerasan dan persuasi, otoritas dan pengaruh, saat individu dan yang universal" (Fontana, 1993: 98). Kekerasan terhadap perempuan yang paling banyak adalah berbentuk kekerasan psikis. Kekerasan dalam terjadi akibat kesewenangwenangan dan dominasi yang dilakukan laki-laki 
terhadap perempuan (Dewi Fitriani 2017). Kekerasan terjadi akibat kesewenang-wenangan yang dilakukan oleh kaum laki-laki terhadap perempuan baik kasus asusila di dunia pendidikan, bahkan keluarga (Yudi Prasetyo, 2017) Raymond Williams di Marxisme and Literature (Williams, 1977) menunjukkan beberapa konsep kunci mengenai pengaruh, terutama pengaruh merujuk pada kelas penguasa menindas kelas yang diperintah. faktor budaya patriarki menjadi salah satu penyebab terjadinya kekerasan (Nimade, 2020) mengesampingkan gagasan bahwa perempuan memiliki tugas dan kewajiban untuk tunduk kepada kekerasan (Kurnia Muhajarah, 2016)

My mother was the second youngest of eight siblings, none of whom we saw frequently. She had five brothers and two sisters, and only one of her sisters, my Aunt Marie, who was married to a mechanic and had six children, had ever come to Riley. When my mother's parents were still alive, we'd drive to visit them in Milwaukee, but they died within ten days of each other when I was six, and after that we'd go years without seeing my aunts, uncles, and cousins. My impression was that their houses all were small and crowded, filled with the squabbling of children and the smell of sour milk, and the men were terse and the women were harried; in a way that was not cruel, none of them appeared to be particularly interested in us. (Sittenfeld, 2008: 4)

Sittenfeld menggambarkan pada novel ini bagaimana kehidupan berkeluarga menjadikan seseorang bisa menjadi lebih kuat atau malah lebih baik dalam hal hal kualitas hidup. Peran-peran yang secara budaya dikonsepsikan untuk laki-laki justru dilakukan oleh perempuan. Fenomena ini merupakan wujud perubahan realitas, yang akan memunculkan budaya baru yang egaliter (Achmad Mulyadi,2012). Teks American Wife (2008) ini mengatakan bahwa kehidupan perempuan dalam keluarga pun akan menjadi tidak bisa teratur jika anggota keluarga tersebut terdiri dari banyak anak dan tinggal dalam satu keluarga dalam satu rumah.

\section{Pengaruh Laki-laki terhadap Perempuan}

Pengaruh laki-laki terhadap perempuan terjadi ketika laki-laki yang menjadi kepala keluarga atau pencari nafkah menjadi satu-satunya yang menghasilkan materi atau uang untuk menopang keluarga yang ada. budaya baik itu sistem patrilinial maupun sistem matrilinial tidak berpengaruh pada persepsi gender (Rehasty Dya, 2011). Ayah dari perempuan tokoh utama ini digambarkan sebagai pemilik 
kekuatan dan kekuasaan yang meliputi kemampuan keuangan dan kepala keluarga yang menopang ekonomi sebuah keluarga. Ibu yang ditunjukkan dalam gambaran yang ada ini juga menunjukkan bagaimana dia terpengaruh oleh laki-laki dalam kaitanya dengan kehidupan peran yang dijalani.

The writer is caught between the need to deform and to organize, to remember and to forget in relation to the cultural system from which he takes his language (Goldmann, 1981: 24)

American Wife (2008): Lakilaki Dominan versus Perempuan yang Kuat Teks American Wife (2008) ini memiliki gagasan yang umum, yakni bahwa laki-laki yang dominan dengan perempuan yang kuat. Hal ini digambarkan sebagai dua insan yang sebenarnya saling melengkapi namun akan selalu terdapat tarik ulur kekuatan satu sama lain. Sebagai fenomena sosial, sastra tidak bisa keluar dari tradisi dan norma-norma yang dijunjung tinggi dalam masyarakat di mana penulis tinggal (Wellek, 1977: 94). Wife (2008), peran seorang istri yang sangat penting dalam menunjang karier seorang suami.

Modernitas, perempuan mengalami marginalisasi dalam sektor pekerjaan yang berakibat pada kecenderungan perempuan untuk melakukan pekerjaan informal yang kurang memberikan perlindungan hukum dan upah yang rendah. Di samping itu, faktor subordinat perempuan dalam sosial maupun kultural, stereotipe terhadap perempuan serta pendidikan yang rendah juga turut mempengaruhi diskriminasi perempuan dalam pekerjaan (khusnul Khotimah, 2009). Dalam bidang politik yang menunjukkan bagaimana wanita yang sebenarnya memiliki peran yang sangat besar sebagai istri politisi dan dalam sisi yang lain juga memiliki kekuatan yang sama besarnya dengan politisi tersebut harus terpengaruh oleh pandangan laki-laki yang berkuasa. peran laki-laki dalam wacana kesetaraan gender merupakan hal yang tidak mudah, mengingat begitu besarnya nilai-nilai yang mempertahankan"kekuasaan" mereka selama ini. Konstruk sosial, sebenarnya hal tersebut dapat dilakukan dengan memberikan sudut pandang baru kepada laki-laki, dalam melihat diri laki-laki itu sendiri dan hubungannya dengan perempuan (Gusri Wandi, 2015)

\section{SIMPULAN}

Ambiguitas dalam teks American Wife (2008) karya Curtis Sittenfeld merupakan strategi penulis perempuan Amerika dalam merespon pengaruh laki-laki terhadap perempuan yang mendasarkan pada kehidupan keluarga, politik dan sosial kemasyarakatan sekaligus meneguhkan peran perempuan dalam bidang 
tersebut. Ambiguitas ini menunjukkan resistensi terhadap penilaian bahwa perempuan yang menentang laki-laki adalah bagian yang dianggap buruk dalam masyarakat karena perempuan bergantung pada sumber daya yang disediakan laki-laki. Namun, dalam praktik yang lain gagasan bahwa perempuan memiliki peran yang sama dengan laki-laki dalam persamaan hak mengakses pendidikan menjadikan perempuan menjadi kuat di satu sisi dan di sisi lain dinilai keluar dari nilai. Bentuk bentuk kekuasaan laki-laki yang termanifestasi dalam ketidak adilan karena gender dan dipengaruhi oleh kekuasaan laki-laki ( David, 2015)

Penafsiran ganda penulis novel ini ini merupakan sebuah bentuk menjadi cara bahwa resistensi perempuan terhadap pengaruh laki-laki tidak bisa secara langsung dilawan, namun dibutuhkan bentuk penyerahan diri sebagai bagian diplomasi. Dalam konteks posisi, penulis novel menunjukkan sisi dominasi laki-laki dalam kehidupan keluarga, politik dan sosial kemasyarakatan. Pada sisi yang lain, dia juga menunjukkan bahwa perempuan yang memiliki kecerdasan pendidikan yang tinggi dan bentuk fisik yang dianggap menarik juga dapat mengalahkan dominasi laki-laki. Hal ini sebagaimana terlihat dalam teks kesastraan American Wife (2008) sekaligus dalam praktik kultural ataupun riwayat hidup sang penulis. Ambiguitas menyembunyikan sebuah risistensi perempuan dan juga memperluas perspektif bahwa perempuan dan laki-laki adalah kekuatan yang saling melengkapi dalam kehidupan keluarga, sosial dan juga politik. Paradigma relasi manusia secara etis sering ditandai dengan kesetaraan dan keadilan, pemakaian kekuasaan secara egaliter, kebebasan secara timbal balik, tanggung jawab, komitmen dan kasih terutama dalam konteks keluarga (Dien Sumiyatiningsih, 2013)

\section{REFERENSI}

Bodgan, RC, dan. Taylors. (1975). Introduction to Qualitative Research Method. New Jersey: Prentice Hall.

David. (2015). Pengaruh Kekuasaaan Laki-laki Terhadap Perempuan Dalam Novel The Chronicle of Kartini Karya Wiwid Prasetyo, Jurnal Sastra Indonesia, 4 (1). 1-9.

Dezin, N.K. dan Lincoln, Y.S. (2005). The Sage Hand Book of Qualitative Research. Thousands Oaks: Sage Publication.

Faruk. (2007). Belenggu PascaKolonial, Pengaruh \& Resistensi dalam Sastra Indonesia. Yogyakarta: Pustaka Pelajar.

Fitriani, D. (2017). Kekerasan Terhadap Perempuan Dalam Novel Bidadari Hitam Karya T.I. Thamrin. Jurnal Master Bahasa, 5 (2), 79-87.

Fontana, B. (1993). Pengaruh and Power: On the Relation between 
Gramsci and Machiavelli. London: University of Minnesota Press.

Goldmann, L. (1981). Method in the Sociology of Literature. Trans. and Ed. William Q. Boelhower Great Britain: Basil Blackwell Publisher.

Khotimah, K. (2009). Diskriminasi Gender Terhadap Perempuan Dalam Sektor Pekerjaan. Jurnal Studi Gender dan Anak, 4 (1) , 158-180.

Muhajarah, K. (2016). Kekerasan Terhadap Perempuan Dalam Rumah Tangga: Perspektif Sosio-Budaya, Hukum, dan Agama. Jurnal SAWWA, 11 (2), 127-146.

Mulyadi, A. (2012). Relasi Laki-Laki Dan Perempuan. (Menabrak Tafsir Teks, Menakar Realitas). Jurnal alIhkâ, 17 (2), 247-261.

Prasetyo, Y. dan Haryadi. (2017). Kekerasan terhadap Tokoh Perempuan dalam Novel Seperti Dendam Rindu Harus Dibayar Tuntas dan Lelaki Harimau Karya Eka Kurniawan. Jurnal SELOKA, 6 (2), 152-160.

Putri, N.M. (2020). Dampak Psikologis Dari Kekerasan Dalam Rumah Tangga Terhadap Perempuan Pada Budaya Patriarki Di Bali. Jurnal Kajian Bali, 10 (1), 283-304.

Rahayu, R.D. (2011). Pengaruh Lingkungan Keluarga, Sekolah Dan Masyarakat Terhadap Persepsi Gender Mahasiswa Laki-Laki Dan Perempuan. Jurnal Transdisiplin Sosiologi,
Komunikasi, dan Ekologi Manusia. 5 (3) , 247-260.

Sanditama, E. (2020). Novel Layla Karya Candra Malik: Kajian Psikologi Sastra Dan Nilai Religius. BASASTRA Jurnal Bahasa Sastra dan Pengajarannya , 8 (1), 116-122.

Sittenfeld, C. (2006). The Man of My Dreams. New York: Random House. . (2008). American Wife.

New York: Random House.

Sumiyatiningsih, D. (2013) Pergeseran Peran Laki-Laki Dan Perempuan Dalam

BASASTRA Jurnal Bahasa, Sastra, dan Pengajarannya

Volume 8 Nomor 2, Oktober 2020, P-ISSN 2302-6405, E-ISSN 2714-9765 